\title{
Impact and Uses of Whatsapp Among College Students
}

\author{
K. Meenakshi, T. Anitha, K. Lakshmi
}

\begin{abstract}
Social networking means sharing information through network. It can be personal or official. Social networking sites are the boon to the college students which enhances the communication and connect with many people around the world. It helps the students to have contact with their own old friends who are far away from them and can also build new friends by forming a group. WhatsApp had become an important part in everybody' life like children, adults, teenagers and senior citizens too due to various features of the WhatsApp attracted the users. WhatsApp is free to download and was introduced to interact with the people easily. It has become a part and parcel of the life. The present study is an attempt to study the impact and the uses of WhatsApp with reference to the students of SDNB Vaishnav College for Women Chrompet, Chennai. This exploratory study has been conducted upon 230 respondents with a structured questionnaire. The data was analysed used SPSS packages. The study concludes that students should give importance to their studies instead of giving importance to the WhatsApp. Students should try to restrict the usage of WhatsApp in order to avoid health problems and see to it they are fit.
\end{abstract}

Keywords: Social networking, WhatsApp.

\section{INTRODUCTION}

WhatsApp started in the year 2009, with the tag line "Simple, Personal, Real time messaging". It is a mobile messaging app which allows the users to exchange messages without paying for SMS. It is a text messaging alternative which is used with the help of net connection through data plan or Wi-Fi connection. User can send unlimited number of message and receive message without any restrictions. They can also form groups with their family, friends, co workers etc. They can closely connect with the people in abroad. Once we download the app all our contact list members will be a members in WhatsApp. You can also block the contact number which you don't wish to receive any message. If you don't wish to be a group you can come out of that group through exist group. Apart from texting we can also send photos, videos, call through video and voice call etc.

\section{IMPORTANCE OF WHATSAPP}

Revised Manuscript Received on September 10, 2019.

Mrs. K. Meenakshi, Assistant professor , Department of Business Administration, SDNB Vaishnav College for Women, Chrompet, Tamilnadu, India. (email: meenakshi.kanagarajan@gmail.com)

Mrs. T. Anitha, Assistant professor, Department of PG Commerce, SDNB Vaishnav College for Women, Chrompet, Tamilnadu, India. (email: anithasaravanan20@gmail.com)

Mrs. K. Lakshmi, Assistant professor , Department of Business Administration, SDNB Vaishnav College for Women, Chrompet, Tamilnadu, Chennai (email: lachu_hi@yahoo.co.in)
1. Message : With the internet connection one can send or receive messages from all over the world without any SMS cost

2. Communication: It has voice calls and video call features. We can even communicate with our friends who are outside the country. We can also have face to face interaction with the help of video call.

3. Documents sharing: it enables us to share our photos, videos instantly. Even we can send documents in text, PDF, slide shows etc. We can send documents upto $100 \mathrm{MB}$

4. Chatting: We can keep in touch with our old friends, family members, co workers etc. We can form a group a maximum of 256 people in one group.

Positive Impacts of WhatsApp

* It is an effective tool for education.

* It creates awareness and information about the happening around the world.

* Spreads information to many people at a time by sending message in a group.

* It helps us to communicate and chat with people in abroad.

* It helps us to connect with the friends, relatives and helps to make new friends.

Negative Impacts of WhatsApp

* Students are becoming victims of cyber bullying.

* Hacking of personal contacts.

* Students get addiction to WhatsApp and they fail to concentrate on their studies.

* More usage of WhatsApp affect the physical and mental health of the students,

* Fail to communicate directly. Face to face interaction has been reduced due to WhatApp.

\section{REVIEW OF LITERATURE}

1. Levent Cetinkaya( 2017) The purpose of the study was to explore the effects of WhatsApp use for education and determined the opinions of students towards the process. The analysis indicated that both learning environments have different effects on the success of students and that supporting the traditional environment by using WhatsApp are more effective for the increase of success. For the qualitative aspect of the study, content analysis techniques were employed to analyze the data which were collected by open-ended question forms. The analysis showed that students developed positive opinions towards the use of 
WhatsApp in their courses. Finally, it was suggested that use of WhatsApp in education process be encouraged as a supportive technology.

2. Golam Rabbani Sarker( 2015) attempted to study the impact of WhatsApp messenger with reference to the students of Begum Rokeya University, Rangpur, Bangladesh in the year 2015. This empirical study has been conducted upon 200 respondents with a questionnaire, which was used as a tool of data collection for the survey. The study has revealed that WhatsApp has a profound negative impact on students and adversely affects their education, behavior and routine lives. It messes up much of study time of students and distracts them from completing their assignments. This app has been found to be highly addictive. The study concluded that time management is essential for online activities. Students should give priority to their life and career building instead of giving priority to the WhatsApp.

3. Bhatt and M. Arshad (2016) find out the impact of WhatsApp on youth. Data was collected from 100 samples of youth from Agra, India. Research shows that WhatsApp has positive as well as negative impact on youth. It affects their education, behavior and routine lives. It is highly addictive in nature. Findings show that youths are spending more time on this application rather than spending quality time with their family members.

\section{OBJECTIVES OF THE STUDY}

1. To study the socio economic profile of the college students of SDNB Vaishnav College.

2. To identify the features influenced them to use WhatsApp.

3. To examine the health problem faced by the users using WhatsApp.

4. To make suggestion to overcome the health problems faced by users.

\section{RESEARCH METHODOLOGY}

The Sample respondents are the students of SDNB Vaishnav College for Women Chrompet, Chennai. The researcher used purposive sampling technique to collect a sample of 230 respondents through questionnaire. The data for the study were collected during August 2019. Data analysis was done with the help of SPSS. To achieve the objective of this research, the researcher has used percentage analysis, Likert Summated scaling, Garatte ranking analysis, discriminant analysis and chi square. The study is exploratory by nature as the researcher has explored the impact of WhatsApp among college students.
VI. DATA ANALYSIS \& RESULTS

Table 1. SOCIO ECONOMIC PROFILE OF THE RESPONDENTS

\begin{tabular}{|c|c|c|c|c|}
\hline Attribute & $\begin{array}{l}\text { No. of } \\
\text { Respondents } \\
\text { (230) }\end{array}$ & Percentage & $\begin{array}{l}\text { Chi Square } \\
\text { (P value) }\end{array}$ & Sig \\
\hline $\begin{array}{l}\text { Age } \\
17-20 \text { years } \\
20-23 \text { years } \\
\text { Above } 23 \text { years }\end{array}$ & $\begin{array}{r}120 \\
85 \\
25\end{array}$ & $\begin{array}{l}52 \\
37 \\
11\end{array}$ & $1.982(0.582)$ & Accept $\mathrm{H}_{0}$ \\
\hline $\begin{array}{l}\text { Marital Status } \\
\text { Married } \\
\text { Unmarried }\end{array}$ & $\begin{array}{r}20 \\
210\end{array}$ & $\begin{array}{l}09 \\
91\end{array}$ & $0.789(0.855)$ & Accept $\mathrm{H}_{0}$ \\
\hline $\begin{array}{l}\text { Educational level } \\
\text { Under Graduates } \\
\text { Post Graduates } \\
\text { Research Scholars } \\
\end{array}$ & $\begin{array}{l}127 \\
82 \\
21\end{array}$ & $\begin{array}{l}55 \\
36 \\
09\end{array}$ & - & - \\
\hline $\begin{array}{l}\text { Shift in the college } \\
\text { Day Shift } \\
\text { Evening Shift }\end{array}$ & $\begin{array}{l}113 \\
117\end{array}$ & $\begin{array}{l}49 \\
51\end{array}$ & - & - \\
\hline $\begin{array}{l}\text { Family Type } \\
\text { Nuclear Family } \\
\text { Joint Family }\end{array}$ & $\begin{array}{r}188 \\
42\end{array}$ & $\begin{array}{l}82 \\
18\end{array}$ & $2.228(0.527)$ & Accept $\mathrm{H}_{0}$ \\
\hline $\begin{array}{l}\text { Device used for WhatsApp } \\
\text { Tablet } \\
\text { Mobile phones }\end{array}$ & $\begin{array}{r}22 \\
208\end{array}$ & $\begin{array}{l}11 \\
89\end{array}$ & $2.879(0.411)$ & Accept $\mathrm{H}_{0}$ \\
\hline $\begin{array}{l}\text { Hours Spend on WhatsApp } \\
\text { Less than } 2 \text { hrs a day } \\
2-4 \text { hrs a day } \\
\text { More than } 4 \text { hrs a day }\end{array}$ & $\begin{array}{c}14 \\
30 \\
186 \\
\end{array}$ & $\begin{array}{l}06 \\
13 \\
81 \\
\end{array}$ & $3.983(0.136)$ & Accept $\mathrm{H}_{0}$ \\
\hline \begin{tabular}{|l|} 
Preferred Time \\
Day time \\
Afternoon \\
Evening \\
Night
\end{tabular} & $\begin{array}{l}42 \\
30 \\
60 \\
98\end{array}$ & $\begin{array}{l}18 \\
13 \\
26 \\
43\end{array}$ & $1.666(0.435)$ & Accept $\mathrm{H}_{0}$ \\
\hline $\begin{array}{l}\text { No of group associated } \\
\text { Less than } 2 \text { groups } \\
2-4 \text { groups } \\
\text { More than } 4 \text { groups }\end{array}$ & $\begin{array}{c}70 \\
119 \\
41\end{array}$ & $\begin{array}{l}30 \\
52 \\
18\end{array}$ & $2.981(0.225)$ & Accept $\mathrm{H}_{0}$ \\
\hline $\begin{array}{l}\text { GB in your mobile per day } \\
\text { Less than } 1 \mathrm{~GB} \\
1 \text { to } 2 \mathrm{~GB} \\
\text { More than } 2 \mathrm{~GB}\end{array}$ & $\begin{array}{c}70 \\
119 \\
41\end{array}$ & $\begin{array}{l}30 \\
52 \\
18\end{array}$ & $2.160(0.340)$ & Accept $\mathrm{H}_{0}$ \\
\hline
\end{tabular}

Source Field Survey - August 2019

To determine the level of association between the shift of the students with selected socio economic variables; chisquare test was applied. The null hypothesis tested was:

Ho: The shifts of the students was independent of age, device used, hours spend, preferred time, no of groups and GB in mobile.

Ha: The shift of the students was dependent on the above factors.

Inference: There is no association between the shift of the students with age, device used, hours spend, preferred time, no of groups and GB in mobile.

TABLE 2: MEAN SCORE - WHATSAPP PURPOSES

\begin{tabular}{|c|l|c|c|}
\hline S. No & Purposes & $\begin{array}{l}\text { Score } \\
\text { Value }\end{array}$ & Rank \\
\hline 1 & Entertainment & 4.10 & 1 \\
\hline 2 & Education purpose & 3.48 & 7 \\
\hline 3 & Stay in touch with friends & 3.91 & 3 \\
\hline 4 & Stay in touch with family members & 4.04 & 2 \\
\hline 5 & Business purpose & 3.21 & 9 \\
\hline 6 & Finding a job & 3.10 & 10 \\
\hline 7 & Knowledge sharing & 3.72 & 5 \\
\hline 8 & Express our views, opinion & 3.66 & 6 \\
\hline 9 & Helps to feel closer & 3.30 & 8 \\
\hline 10 & Spreads information faster & 3.80 & 4 \\
\hline \multicolumn{2}{|c|}{ Mean Score } & $\mathbf{3 . 6 3}$ \\
\hline
\end{tabular}

Source Field Survey - August 2019 


\section{Interpretation}

The purposes of WhatsApp used among the college students were determined on the basis of mean score of all the statements of respondents, which came out to be 3.63 for the sample respondents. The purposes are entertainment, stay in touch with family members stay in touch with friends, spreads information faster, knowledge sharing and express our thoughts have mean score exceeding 3.63 implying their purpose of using WhatsApp. However their perception regarding the purpose such as Education purpose, helps to feel closer, business purpose and finding a job had mean score less than 3.63 , which conclude that the purpose has less priority when compared to the previous factors.

\section{TABLE 3: MEAN SCORE - SATISFACTION WITH} THE FEATURES OF WHATSAPP

\begin{tabular}{|c|l|c|c|}
\hline S. No & Features & Score Value & Rank \\
\hline 1 & Message & 4.40 & 1 \\
\hline 2 & Video call & 4.08 & 5 \\
\hline 3 & Voice call & 4.10 & 4 \\
\hline 4 & Send photos and videos & 4.31 & 2 \\
\hline 5 & Group creation & 4.00 & 6 \\
\hline 6 & Status updating & 4.20 & 3 \\
\hline 7 & Audio message & 3.75 & 7 \\
\hline \multicolumn{2}{|c|}{ Mean Score } & $\mathbf{4 . 0 7}$ \\
\hline
\end{tabular}

Source Field Survey - August 2019

\section{Interpretation}

The level of satisfaction with the features of WhatsApp among the college students were determined on the basis of mean score which came out to be 4.07. The respondents are highly satisfied with message, sending photos and videos, status updating, voice call and video call have mean score exceeding 4.03. However the satisfaction regarding the group creation and audio message have mean score less than 4.03 which conclude that the satisfaction was less as compared to previous factors.

\section{TABLE 4: RANK THE PREFERENCE OF USING} WHATSAPP

\begin{tabular}{|c|l|c|c|}
\hline S. No & \multicolumn{1}{|c|}{ Variables } & Score Value & Rank \\
\hline $\mathbf{l}$ & Chatting & 81.9 & 1 \\
\hline $\mathbf{2}$ & Calling & 66.1 & 5 \\
\hline $\mathbf{3}$ & Photos sharing & 76.4 & 2 \\
\hline $\mathbf{4}$ & Status updating & 75.4 & 3 \\
\hline $\mathbf{5}$ & Information sharing & 67.8 & 4 \\
\hline
\end{tabular}

Source Field Survey - August 2019

\section{Interpretation:}

From the above table it is inferred that the preference of using WhatsApp : chatting ranked first with the score of 81.9 , followed by photos sharing with the core 76.4 followed by status updating with score of 75.4 followed by information sharing with a score of 67.8 and calling with a score of 66.1 respectively.
TABLE 5: MEAN SCORE - HEALTH ISSUES FACED BY THE RESPONDENTS

\begin{tabular}{|c|l|c|c|}
\hline S. No & Health Issues & Score Value & Rank \\
\hline 1 & Poor sleeping & 3.90 & 1 \\
\hline 2 & Eye strain & 3.81 & 2 \\
\hline 3 & Depression & 2.90 & 7 \\
\hline 4 & Stress & 3.40 & 5 \\
\hline 5 & Fatigue & 3.02 & 6 \\
\hline 6 & Neck ache & 3.75 & 3 \\
\hline 7 & Head ache & 3.52 & 4 \\
\hline \multicolumn{2}{|c|}{ Mean Score } & 3.47 \\
\hline
\end{tabular}

Source Field Survey - August 2019

\section{Interpretation}

The health issues faced by the respondents are determined on the basis of mean score which came out to be 3.47. The respondents faced problems like poor sleeping, eye strain, neck ache and head ache have mean score exceeding 3.47. However the problems like stress, fatigue and depression have mean score less than 3.47 which conclude that these problems were less as compared to previous factors.

\section{TABLE 6: EDUCATIONAL QUALIFICATION AND LEVEL OF HEALTH ISSUES}

\begin{tabular}{|l|l|l|l|l|l|l|l|l|}
\hline \multirow{3}{*}{$\begin{array}{c}\text { Educational } \\
\text { Qualification }\end{array}$} & \multicolumn{7}{|c|}{ Level of Health Issues } \\
\cline { 2 - 10 } & Low Level & \multicolumn{2}{|c|}{ Medium Level } & \multicolumn{2}{c|}{ High Level } & \multicolumn{2}{c|}{ Total } \\
\cline { 2 - 9 } & No $_{0}$ & $\%$ & $\mathrm{~N}_{0}$ & $\%$ & No $_{0}$ & $\%$ & No $_{0}$ & $\%$ \\
\hline UG & 23 & 41.07 & 63 & 55.75 & 41 & 67.21 & 127 & 55.21 \\
\hline PG & 25 & 44.64 & 40 & 35.39 & 17 & 27.86 & 82 & 35.65 \\
\hline Research Scholars & 8 & 14.29 & 10 & 08.86 & 3 & 05.93 & 21 & 09.14 \\
\hline Total & 56 & 100 & 113 & 100 & 61 & 100 & 230 & 100.00 \\
\hline
\end{tabular}

Source Field Survey - August 2019

In the above table, the classification accuracy percentage of the discriminant function was lower health issues (56), Medium health issues (113) and higher health issues (61) thus the discriminant function was quite efficient in analyzing the respondents on the basis of health issues into high, medium and low health issues. There exist the medium health issues among the college students.

\section{RECOMMENDATIONS}

* Message can be sent to more than 5 persons at a time.

The photo size can be increased from $100 \mathrm{MB}$ to $250 \mathrm{MB}$. So that long size photos can be easily shared.

* The contacts in a group can be increase from 256 members to 500 .

* Annual maintenance charges can be reduced.

* Status updation can be expired after 48 hours.

* Time management is very essential. User should try to balance the career and the entertainment without any conflict.

* Students should give importance to their studies instead of giving importance to the WhatsApp.

* Students should restrict the usage of WhatsApp in order to avoid health problems. 


\section{CONCLUSION}

WhatsApp has become a part and parcel of the life of the people. The users are spending more time on mobile and WhatsApp in specific. The uses and popularity of WhatsApp is increasing due to user friendliness. The college students are very effectively using the WhatsApp and it has a very good impact among the college students. Low internet connection and insufficient GB were the problems faced by the students in using WhatsApp. It is clear that there exist the medium health issues among the college students. The study concludes that students should give importance to their studies instead of giving importance to the WhatsApp. The usages of WhatsApp among the students are very high and they should try to restrict the usage of WhatsApp in order to avoid health problems and see to it they are physically fit.

\section{REFERENCES}

1. Levent Cetinkaya( 2017) "The Impact of WhatsApp Use on Success in Education Process", International Review of Research in Open and Distributed Learning Volume 18 , Number 7, November .

2. Golam Rabbani Sarker (2015) "Impact of WhatsApp messenger on the university level students: A sociological study", International Journal of Natural and Social Sciences, 2(4): 118-125.

3. Bhatt, A and Arshad, M (2016) "Impact of WhatsApp on Youth: A Sociological Study" IRA- International Journal of Management and Social Sciences, 4(2): 376-386. 